\title{
Oorsake van kerkkrimping binne die tradisioneel Afrikaanssprekende gereformeerde kerke in Suid-Afrika
}

\author{
Authors: \\ Ben Jacobus De Klerk ${ }^{1}$ \\ Phia Van Helden ${ }^{1}$ \\ Affiliations: \\ 1Practical Theology, \\ North-West University, \\ Potchefstroom Campus, \\ South Africa \\ Correspondence to: \\ Ben de Klerk \\ Email: \\ ben.deklerk@nwu.ac.za \\ Postal address: \\ PO Box 147, Potchefstroom \\ Campus, North-West \\ University, Private Bag \\ X6001, Potchefstroom 2520, \\ South Africa \\ Dates: \\ Received: 12 Nov. 2010 \\ Accepted: 15 Mar. 2011 \\ Published: 24 June 2011 \\ How to cite this article: \\ De Klerk, B.H. \& Van \\ Helden, P., 2011, 'Oorsake \\ van kerkkrimping \\ binne die tradisioneel \\ Afrikaanssprekende \\ gereformeerde kerke in Suid \\ Afrika', Verbum et Ecclesia \\ 32(1), Art. \#477, 10 pages. \\ doi:10.4102/ve.v32i1.477
}

(C) 2011. The Authors.

Licensee: OpenJournals

Publishing. This work

is licensed under the

Creative Commons

Attribution License.
The focus of this article was to pursue factors regarding the declining numbers in the traditional Afrikaans speaking reformed churches in South Africa. This intertwined phenomenon was studied according to theonome reciprocity as portrayed in the covenant and embedded in the Great Commission. The unstoppable drive of the Spirit is recognised in a levelling wave approximately every 500 years. It is also recognised in the wave where mainstream Christianity moves from the northern to the southern hemisphere, as well as cyclic movements typical to the Christian religion. Man's involvement is categorised as factors that are difficult to measure, as well as factors that can be measured. Paradigms, as factors difficult to measure and contributing to the decline of churches, form the background to the manifestation of the measureable factors.

\section{Inleiding}

Kerkkrimping as verskynsel binne die tradisioneel Afrikaanssprekende gereformeerde kerke is aan die begin van die 21ste eeu toe te skryf aan 'n menigte faktore. Hierdie faktore word vervleg en werk kompleks mee om die verskynsel te laat manifesteer binne die eens gerekende, protestantse hoofstroom kerke en hartland van die Christendom wat na die ontwikkelde wêreld georiënteer is (Walls 2002:61-72, 95-107, 195-214). Die verskynsel het sedert 1980 sterk na vore begin kom en teen 1990 is dit as onomkeerbare tendens in Suid-Afrika bevestig (Hendriks 1993:545). Kerkkrimping is die resultaat van die sameloop van historiese en hedendaagse meetbare en onmeetbare faktore binne en buite die gelowige(s), te midde van die onstuitbare voortstuwende beweeglikheid van die Christendom. Faktore wat aanleiding gee tot kerkkrimping kan derhalwe wel onderskei word, maar weens die verweefde aard daarvan is skeiding van die onderling beïnvloedende faktore nie moontlik nie. Hierdie artikel vra die dringende vraag na die totale opset van die oorsake van krimping binne die tradisioneel Afrikaanssprekende gereformeerde kerke in Suid-Afrika (praktyk), maar terselfdertyd word ook gevra na wat die Groot Opdrag (teorie) binne sodanige konteks beveel.

Om die totale opset van die oorsake te verstaan, is dit nodig om alle faktore te reken teen 'die onsigbare dimensie van die Goddelike werklikheid' (Van Ruler 1969:181; vgl. ook De Wet 2005:505525) wat in ' $n$ ineenverweefde verhouding staan met die mens en sy sigbare werklikheid. Die 'geheim van die verhouding' (Van Ruler 1969:181) dui op verbondsmatige aktiwiteit, ook bekend as teonome resiprositeit (De Wet 2005:505-525; Van Ruler 1969:181-187). Teonome resiprositeit is direk en duidelik in die Groot Opdrag ingebed. Die Groot Opdrag kan derhalwe as sleutel gebruik word om die 'geheime' rondom die verskynsel van kerkkrimping, maar ook rondom kerkgroei, te ontrafel en die mens te rig tot gehoorsaamheid aan die laaste opdrag van Jesus (vgl. Cilliers, 1994:252-255; Nürnberger, 2002:75-76; Strong, 2007:107-109; Heitink et al, 2000:60).

In die lig hiervan word die onstuitbare voortstuwing van die Gees, maar ook die onafwendbare rol en betrokkenheid van die mens binne die verskynsel van kerkkrimping, in hierdie artikel bespreek. Die mens se aandeel fokus op moeilik meetbare faktore, maar ook op meetbare faktore. Navorsing hieroor het plaasgevind deur histories-grammatiese eksegese, literatuur- en statistieknavorsing, insette vanuit ander dissiplines, asook deur kwalitatiewe en kwantitatiewe empiriese navorsing ('n steekproef in die Gereformeerde Kerke van Suid-Afrika). Deur Aksie Navorsing en Waarderende Ondersoek is gekom tot'n gereformeerde voorstel vir'n verbeterende kerkpraktyk. Weens gebrek aan spasie sou laasgenoemde aantal aspekte van die navorsing eerder in moontlike opvolg-artikels bespreek kan word.

\section{Teonome resiprositeit}

Die bipolariteit van die sleutel fokus op God en die mens binne ' $n$ verbondsverhouding (Bosch 1991:18). God as inisieerder van alle heils-aktiwiteite het met die laaste opdrag wat Jesus op aarde gegee het (Groot Opdrag: Mat 28:18-20 en Hand 1:8) uitbreiding en groei uitgespel. Die basis van die Groot Opdrag wat aan die mens gegee is, is geleë in die indikatief en die imperatief 
van die teksdele (Van der Walt 2007:168). Die indikatief dui op die magsaankondiging en vaste belofte van bystand deur God, terwyl die imperatief die aktiwiteit van die mens aantoon. Deur die inbou van die mens as gebroke, dog herskepte sondaar, is die teendeel van uitbreiding en groei, naamlik krimping of kwyning, ook implisiet uitgespel. Die bedoeling wat in die Groot Opdrag geleë is, is dat die menslike aktiwiteit deur 'n eenheidsisteem van opbou en uitbou manifesteer ter wille van God se raadsbesluit rakende die mens se heilsbestemming (Burger 1999:88, 111, 149, 150; Schalekamp 2005b:31, 34).

Die verbondsverhouding of -aktiwiteite geskied binne tyd en ruimte (Walls 2002:73-80). God as missionêre God werk onstuitbaar voort, terwyl daar van die mens dieselfde doelgerigte ingesteldheid verwag word (Bosch 1991:392). Die teendeel realiseer egter; aangesien die mens in swakheid optree weens sy gebrokenheid en derhalwe telkens nie opgewasse is om die opdrag stiptelik te gehoorsaam nie. Die skeefgetrekte verbondsverhouding bewerkstellig bedroewing, uitdowing en selfs die blus van die Gees. Ten spyte hiervan werk die Gees onstuitbaar voort.

\section{God se aandeel: Onstuitbare voortstuwing}

Kenmerkend van die beweeglikheid van die Christelike godsdiens is die golfbewegings wat onstuitbaar voortrol. Hierdie golfbewegings kan toegeskryf word aan die Gees se aktiwiteit wat gevestigde godsdiensuitlewing wysig en nuwe omstandighede daarstel om voortdurend vernuwende uitbreiding van die evangelie te verseker (Tickle 2008:13-17).

\section{Gelykmakende golfbewegings ongeveer elke $\mathbf{5 0 0}$ jaar}

Die afgelope 2000 jaar het 'n vaste golfpatroon ongeveer elke 500 jaar gemanifesteer. Nadat die eerste Christene in Antiochië die Christelike godsdiens aanvaar het, is die eerste golfbeweging teen ongeveer 500 n.C. bespeur, hoofsaaklik deur die toedoen van Gregorius die Grote. Dit speel af teen die verdwyning van die Romeinse Ryk en die Donker Eeue wat in aanvang neem. Die tweede golfbeweging bereik teen 1054 'n hoogtepunt met die Groot Skeiding tussen Rome (Katolisisme) en Konstantinopel (Griekse Ortodoksie). Die derde golfbeweging piek teen 1517 met die Wittenbergstellings, terwyl die vierde golfbeweging met die 21ste eeu steeds momentum opbou om die volgende radikale groot ontluikende verskuiwing daar te stel (Tickle 2008:19-28). Dis belangrik om kennis te neem dat die ontluikende verskuiwing nie op vernietiging van die godsdiens dui nie, maar wel dat 'n onstuitbare mag 'n totaal nuwe uitlewing van godsdiens daarstel. Gelowiges van die 21ste eeu verkeer derhalwe midde 'n onafwendbare oorgangsfase (Du Toit 2000:57-62).

\section{Golfbeweging vanaf die noordelike na die suidelike halfrond}

Die hartland van die protestantisme as hoofstroom Christelike geloof is histories geleë in die blanke lande in die ontwikkelde wêreld van die noordelike halfrond. Hiervandaan is die evangelie eeue lank uitgedra, hetsy deur sendingaksies of kolonisasie. Die eeuelange, skynbaar stilswyende enkulturasieproses ontkiem egter in die huidige oorgangstyd en lewer die vrug op sendingaktiwiteite: 'n verskuiwing van die Christelike hartland na die globale suidelike halfrond (Suid-Amerika, Afrika suid van die Sahara, Asië). Die geweldige golfbeweging toon 'n ontsaglike opbou in momentum binne lande in die ontwikkelende wêreld, waar inheemse kerke op multikulturele en sinkretistiese wyse die Christelike geloof binne die charismatiese interpretasiewyse aanneem.

Die charismatiese stroom in Suid-Afrika se sukses deur bemagtiging en deur die bied van 'n geestelike tuiste vir die 'have-nots' ['n individu of groep sonder finansiële en sosiale sekuriteit of ander materiële voordele], (Jenkins 2007:14-15, $107,125)$, oortref die tradisionele gereformeerde hoofstroom getallegewys by verre. Die beweging wat tans plaasvind, fokus derhalwe op die groei van die charismatiese stroom en die krimping van die tradisionele hoofstroom, waaronder gereformeerdes tel.

Opmerklik binne die oorgangsfase waarby die totale multikulturele gelowige bevolking in Suid-Afrika betrokke is, is dat ' $n$ identiteitskrisis bestaan by die krimpende tradisionele 'susterskerke', wat na die ontwikkelde wêreld georiënteer is, sowel as by die groeiende Afrikageoriënteerde charismaties-sinkretistiese kerke (Jenkins 2007:161; Hendriks 1996:143; 1999:17-18). In die soeke na identiteit en denkherstrukturering bestaan die moontlikheid van ' $n$ verdere golfbeweging in die groeiende charismatiese stroom, naamlik die 'revolving-door syndrome' [swaaideursindroom] (Barret et al. 2001:19). Hiervolgens kan die magtige charismatiese stroom, weens onvolhoubare bemagtiging van die enorme getalle, ' $\mathrm{n}$ 'advance and recession'-tendens [vooruitgang en insinking] ervaar wat tot kerkloosheid kan lei. Die beweging van die suidelike charismatiese Christendom kan volgens hierdie tendens grootliks oorgaan in nihilisme (Du Toit 2000:180).

Aan die ander kant, by die kwynende gereformeerde kerke word die soeke na identiteit en herstrukturering gekniehalter deur 'n onvermoë om denke radikaal volgens Romeine 12:2, die Groot Opdrag en die nuwe-wyn-nuwe-sak-beginsel (Mat 9:17) aan te pas. Stagnasie of onveranderlikheid van hartsdenke is in die proses om tot verdwyning van die tradisionele stroom te lei.

\section{Golfbewegings binne die tradisionele stroom}

Die tradisionele stroom in Suid-Afrika het 151 jaar gelede in drie kerkverbande verdeel. Elke gemeente binne elke kerkverband het so hul lewenssiklus begin terwyl gemeentes wat later ontstaan het, eweneens later 'n lewenssiklus begin het. Elke siklus vertoon' $n$ groei- en 'n krimpfase. Die groeifase bestaan uit diegeboorte-, kleuter-, tiener-en fleurstadia, terwyl die krimpfase die volwasse-, aristokratiese-, burokratiese- en sterfstadia behels (Brouwer et al. 2007:16-20, 105; Saarinen 
1992:1-23). Hoe lank een fase binne 'n spesifieke gemeente duur, hang af van die unieke sameloop van talle interne en eksterne faktore, asook openheid teenoor verandering of reformasie. Volgens Brouwer, vermy hooflynkerke kerksluiting (sterwe). Terselfdertyd word weinig aandag aan dié fase geskenk, omdat daar op oorlewing gefokus word. Volgens Van Rooy (2006:22) is die tradisionele stroom aan die begin van die 21ste eeu midde ' $n$ 'oorlewingstryd'. Indien verandering of herlewing wel plaasvind, manifesteer dit as 'n groei- of societas-golfbeweging (Burger 1995:23-25) binne die lewenssiklus (Brouwer et al. 2007:16-20, 105; Saarinen 1992:123). Verandering of herlewing kan plaasvind deurdat nuwe aktiwiteite, benaderings of programme daargestel word of wanneer ' $n$ nuwe pastor deel word van sodanige gemeente. Indien die societasbeweging kwyn, tree die krimping- of communitasbeweging in en golf die lewenssiklus bloot voort.

Blywende herlewing kan bewerkstellig word, deurdat elke geslag bewus is van voortdurende denkverandering, bekering en reformasie (Rom 12:2, Groot Opdrag, Mat 9:17). Bereidheid tot diepgaande verandering in die wete dat beweging die reël binne gemeentelike lewe is, is verder noodsaaklik, terwyl die status quo wat lei tot krimping, bewustelik voorkom moet word.

Gesien teen die onstuitbare werking van die Gees, is dit duidelik dat die mens deur voortdurende denkverandering die eenheidsisteem aktief moet nastreef om in pas te bly met die veranderende omstandighede wat voortdurend deur die Gees, ter wille van die evangelie, bewerkstellig word. In Suid-Afrika eis die huidige omstandighede radikale denkverandering, drastiese identiteits-aanpassings en ernstige gehoorsaamheid aan die Groot Gebod (De Klerk 2000:451-468). Slegs hierdeur kan die sterwende tradisionele kerk, op totaal nuut-aangepaste wyse, deel vorm van die ontluikende stroom om ná die denkmetamorfose dan as missionêre stroom, soos 'n Gideonsbende teen die groeiende heidendom, uit te marsjeer.

\section{Die mens se aandeel}

Faktore wat aanleiding gee tot kerkkrimping en waar die mens betrokke is, kan verdeel word in moeilik meetbare faktore en meetbare faktore.

\section{Moeilik meetbare faktore: Denkstrome en -ismes}

Sedert die Verligting het geweldige verskuiwings op alle vlakke van die lewe plaasgevind. Die ingrypende ontwikkelinge op die gebied van wetenskap (Bosch 1999:264-317) het alle mense beinvloed. Gelowiges is ontnugter. Dit het gelei tot grootskaalse geloofskrisisse en denkwysigings. Onbeantwoorde vrae word in die huidige tydsgewrig steeds toenemend as dualisties ervaar en plaas die geloofwaardigheid, integriteit en relevansie van die kerk toenemend onder verdenking (Du Toit 2000:33, 61, 182, 183). Dit lei tot onttrekking van kerklike betrokkenheid, met krimping as gevolg.
Sekularisme, ontkerstening, afname in Godsbegrip en toename in ongeloof, te midde van globalisme, pluralisme, materialisme, individualisme, die denk herstrukturering binne ' $n$ versplinterde postmodernistiese samelewing, veroorsaak'n subjektiwistiese lewenswyse wat kerkkrimping grootliks voed (Gill 2003:5, 6, 17; Niemandt 2007:22; Tickle 2008:50). Gill (2003) en Björk (2006:321) stel voor dat sekularisme as sambreelterm vir hedendaagse denkstrome inderdaad bepalend is vir die tendens van kerkkrimping, maar dat die (kwynende) verbondsverhouding van die individu die werklik bepalende faktor is.

Die mens se subjektiewe reaksie, veral tydens onstabiele tye (Ward 2004:11), kan groepeer word in twee reaksiegroepe. Aan die een kant manifesteer geslotenheid wat die gevolg is van konserwatiewe of fundamentalistiese denke en aan die ander kant manifesteer totale openheid as gevolg van progressiewe of liberale denke (Du Toit 2000:36-49; Venter 2006:229, 231, 232). (Ultra)konserwatiewe denke wat by tradisionele gereformeerdes voorkom, lei tot introverte laervorming, min aanpassingsvermoë, asook gebrek aan leierskap, visionering en missionêre gerigtheid. Groepering as gevolg van reaktiewe denke lei tot onderlinge wantroue, onenigheid, onttrekking en toename in randlidmate. Randlidmate is weens voortdurende onsekerhede ongeneë om by die tradisionele denominasie te bly, alhoewel hulle steeds godsdienstig is (Tickle 2008:64-66, 91-93, 131, 133, 149). Hierdie tendens werk nadelig in op gemeentelike lewe en werk kerkkrimping in die hand.

Die subjektiwistiese gelowige van die 21ste eeu toon, ten spyte van afname in kerkgang, 'n sterk geneigdheid tot spiritualiteit (Smit \& Vorster 2000:516-519). Die spiritualiteit van die ontwortelde of onsekere gelowige fokus op dit wat nog oorbly, naamlik die gesag van Christus deur die Gees binne die mens (Woodhead 2004:335; Brouwer et al. 2007:40, $58,183)$. Die magsbasis van die hedendaagse gelowige is derhalwe binne die mens self gesetel, dog gebou op die Heilige Gees; gelowiges beskou die tradisionele kerk daarom nie meer as 'n gesagvolle tuiste nie, maar ook omdat die ouer geslag bemagtiging van die hedendaagse anders-ervarende mens nie as prioriteit reken nie (Hendriks 2003). Alhoewel die hoofstroomkerke mettertyd wel aan omstandighede erkenning moet gee, is die stadige aanpasbaarheid van die tradisieverknogte instellings totaal ontoereikend; die gevolg is dat die kerk nie meer opgesoek word nie (Cameron et al. 2005:51, 84; Heitink 1979:331; Olivier 2005:79, 82).

Gelowiges vertoon dus ' $n$ nuwe en anderse spiritualiteit, wat in 'n totaal nuwe godsdiensuitlewing manifesteer (Roxburgh 2007). Weens grootskaalse miskenning van die nuwe postmoderne spiritueel-geneigdheid in gelowiges en die gebrek in die bediening van dié mens en sy behoeftes, soek die gelowige 'n tuiste waar bediening of bemagtiging wel gebied word. Indien dit nie gesoek of gevind word nie, ontstaan die verskynsel van kerklose gelowiges (Ward 2004:3). In baie gevalle word ' $n$ ander denominasie opgesoek. Die charismatiese stroom maak voorsiening vir die bediening 
of bemagtiging van dié mens en grootskaalse oorlopery vind plaas. Hierdie tendens versterk krimping van die tradisionele kerke (Tickle 2008:64-66; Woodhead 2004:347, 410).

\section{Meetbare faktore}

\section{Ontvolking, verstedeliking, geboue, kerkbesoek en geboorte-afname}

Ontvolking van die platteland, asook verstedeliking, is van die opvallendste verskynsels ter bevestiging van kerkkrimping. Weens die verdeling van die 'susterkerke' in 1859, is daar in bykans elke dorpie landswyd drie kerke, met baie sitplek, opgerig. Aangesien talle lidmate mettertyd na stede verhuis het, het hierdie geboue bloot leë sitplekke oorgehou, terwyl die snelgroeiende stedelike opset nie gereed was om vir hierdie invloei voorsiening te mak nie (Kane-Berman 2007:21). Talle stedelinge het bloot in die stad 'verdwyn' (Gill 2003:3-4).

Kerkbesoekdata bevestig dat kerkbesoek toenemend afneem (Van der Walt 2000; Vogel 2008; Gaum 1990; Symington 2007; Dreyer 1990; Beukes 2007). Wanneer krimping of sterwe, veral in die platteland, waargeneem word, is 'n algemene emosionele reaksie om aan die kerkgebou vas te klou. Telkens is bewys dat indien die kerkgebou verkoop word, die gemeente ook uiteenspat (Olivier 2006:80, 128-129).

Statistiek van die afgelope drie dekades toon konstante en drastiese afname in geboortesyfers (Giliomee 2004:540; Hendriks 1993:548-549). Die jong geslag wat kindergetalle binne die tradisionele kerke daar moet stel, is grootliks afwesig. Die afwesigheid van die jong geslag word toegeskryf aan vrees vir die toekoms, wat bevestig word deur die emigrasiesyfers. Die afwesigheid van 'n gesonde bevolkingsprofiel word beklemtoon deurdat die grootste deel van die Wit bevolking persone tussen 40 en 50 is (Van Aardt 2006:4). Verder is die gelowige jongmense wat wel nog in die land is, afsydig rakende gesinsvorming. Hulle word hierin ondersteun deur die keuses wat uitgeoefen kan word rakende voorbehoedmiddels wat omstandighede daarstel wat die beroepslewe vir die vrou meer aanloklik maak. Hierby is die materiële ingesteldheid en voorspoed wat beroepsgerigtheid vir die man en vrou, ten koste van kindertoevoeging, meebring, kontraproduktief vir die Afrikanerbevolking, asook vir die kerk (Tickle 2008:112-115). Dis ook 'n feit dat hoër inkomstegroepe die grootste afname in geboortesyfers toon.

Getalswakte is 'n onaangename werklikheid. Indien die negatiewe bevolkingsgroei van $-8.08 \%$ volhou, word voorspel dat die 4634659 Wit Suid-Afrikaners (2001) slegs 4 260232 in 2021 sal beloop (Kane-Berman 2007:12) Die kerk ly ook grootliks hieronder.

\section{Ekonomiese, politieke en sosiale faktore}

Ekonomiese, politieke en sosiale faktore is nou verweef en maak deel uit van enige vervlegte wysigingsaktiwiteit (Brouwer et al. 2007:40-47). Indien immigrante Suid-Afrika weens ekonomiese redes binnekom, word tradisioneel Afrikaanse kerke nie vir lidmaatskap oorweeg nie. Tradisionele kerke is ook nie voorbereid om verskeidenheid te akkommodeer nie. Wanneer kerklidmate weens ekonomiese redes in ander lande gaan werk, is hul plek onmiddellik leeg. Indien hulle ooit terugkeer na Suid-Afrika, word die tradisionele kerke selde weer oorweeg, aangesien diegene wat terugkeer nie meer inpas by die tradisionele kerkopset nie.

Die feit dat ' $n$ hele geslag Wit mense die land verlaat het (Van Aardt 2006:4), toon dat die land steeds in 'n skokfase is weens die politieke verandering (1994). Die regering se uitgangspunt rakende regstellende aksie, asook talle regeringsuitlatings, wat by die Wit bevolking vrees en gebrek aan sekuriteit bevorder, tesame met die onvermoë om misdaad te beheer, het emigrasie grootliks bevorder (Giliomee 2004:619, 620; Hendriks 2000:75; Kane-Berman 2007:11, 251, 489-490).

Die gevolg van regstellende aksie is dat die land grootliks aan vaardighede kortskiet. Weens die ANC-ingesteldheid word voorkeur gegee aan buitelanders met vaardighede wat in aanvraag is, terwyl die Afrikanerburger nie oorweeg word nie. Hierdie optrede het die negatiwiteit by Afrikaners versterk. Teen 2003 het emigrasiesyfers reeds 16165 beloop (Kane-Berman 2007:44, 47). Weens emigrasie het getalle in die Nederduits Gereformeerde Kerk van 3527075 tot 3005697 afgeneem.

Sosiaal het hierdie omstandighede veroorsaak dat die Afrikaner na die periferie verskuif is (Du Toit et al. 2002:45; Oliver 2007:32). Die skok het wantroue in die kerk versterk, omdat die geloofsuitgangspunt van die Afrikaner voor en tydens die apartheids-era met ' $n$ analogie-skematisme gewerk het en goedertrou gebou is op die Corpus Christianum-idee (Hendriks 2000a:294; Hofmeyr \& Pillay 1994:228-229). In die lig van die politieke omwentelinge kon die kerk nie antwoorde op vrae hieruit voortspruitende bied nie. Die skok dra by tot gebrek aan geloofwaardigheid, geloofskrisisse en identiteitsverlies (Hendriks 2000a: 292-293). Dit lei tot negatiwisme, onbetrokkenheid en 'n 'lamsakkige ingesteldheid' (Hendriks 2000a:292), waardeur kerkbesoek direk geraak word. Oorlopery na ander kerke en denominasies word grootliks hierdeur aangemoedig (Erasmus \& Hendriks 2003:81; Oliver 2007:23-40).

Hiermee gepaardgaande, het morele onsekerheid skielik sedert 1994 begin manifesteer, aangesien liberalisering deur openbare sedelikheidswetgewing geskied het. Dit het veroorsaak dat lidmate wat nie persoonlik verantwoordelikheid vir hul waardes wou aanvaar nie, morele onsekerheid begin ervaar het (Erasmus \& Hendriks 2003:81). Die gevoel van vervreemding en magteloosheid is verder deur die onsuksesvolle versoenings-intensies van die WVK vererger. Tydens dié proses was die tradisionele kerk bloot in 'n toeskouersposisie (Du Toit et al. 2002:3, 4, 44, 48; Giliomee 2004:612). Die oorlewingsywer van die Afrikaner het 'n geweldige knou gekry, aangesien die diepste uitingsvorm van 'n 'geroepe' (Giliomee 2004:626) volk in diens van God, die Afrikaner ontneem is. 
Die krisis het verder verdiep deurdat Afrikaans beskerming verloor het en afgeskaal is. Afrikaans as eens saambindende instrument word skynbaar as uitgedien beskou (Giliomee 2004:562, 622-626, 630). Die vervlegte omstandighede het tot gevolg dat die Afrikaanssprekende aan die begin van die 21ste eeu gekenmerk word as 'n terugtrekkende, krimpende groep.

\section{Tegnologie en die huislike opset}

Tegnologiese toerusting en gepaardgaande vaardighede binne die privaatheid van die gesinsopset, getuig van ekonomiese voorspoed. Die krimpende gereformeerde kerke val grootliks binne hierdie groep. Die invloed van tegnologie, gesien teen globalisasie (Erasmus \& Hendriks 2003:81) en die onttrekking as gevolg van die ekonomiese, politieke en sosiale omstandighede, is ingrypend (Tickle 2008:51, 104-108). Die oorgangsfase waarin die samelewing verkeer, het tot gevolg dat ook die gesinskultuur radikaal verander. Afwesige ouers, hoofsaaklik weens 'n materiële instelling (Buchner 2002:12), veroorsaak dat basiese waardes, asook godsdienstige gebruike, nie meer binne die huisgesin geleef en ervaar word nie (Tickle 2008:112-115). Die primêre instansie wankel, hoofsaaklik omdat ouers nie meer die gereformeerde werklikheid uitleef nie. Vervreemding van die gereformeerde leefwyse word versterk deurdat die ouers niks bied waarin kinders kan glo nie. Die primêre sosialiseringsproses word derhalwe met die sekondêre vervang. Gevolglik neem die rekenaar, elektroniese vermaak en die televisie in baie huishoudings die plek van die Bybel in (Cameron et al. 2005:85; Rall 2007:12).

Diegene wat steeds die kerk besoek, ervaar gereeld 'n dualisme en ongeneigdheid tot assosiasie deurdat die kerk 'agtergeblewe' vertoon indien tegnologie, wat die hedendaagse lewe kenmerk, afwesig is. Vervreemding van die kerk as irrelevante tradisionele instelling word sodoende versterk (Dreyer 2009:13; Olivier 2006:120, 152).

Keuses, byvoorbeeld of die kinders kerk toe wil gaan of nie, of toegegee word aan seisoenale faktore (weer, jaarkalender), of blootstelling aan verskeidenheid kerke, raak veral die opkomende geslag in die ouerhuis onder die huidige ylgelowige ouerkorps. Hierdie gebrekkige oordragsproses staan bekend as afkoelteologie (Tickle 2008:131-132; Hendriks 1996:143; Jansen 2008:14). Ook sosioloë toon aan dat gebrekkige oordragspatrone as gevolg van die laksheid van ouers, gelyklopend met die generasiegaping, as direkte rede vir kerkkrimping gereken word (Altemeyer 2004:77-89; Crockett \& Voas 2006:567-584; Stilma 1988:25, 27, 76, 96).

\section{Die wese van die Afrikaner}

Tot dusver is aangetoon dat die Afrikaner aan die begin van die 21ste eeu onwillekeurig onderhewig is aan invloede van verskillende denkstrome en die drastiese ekonomiese, sosiale, politieke en tegnologiese ontwikkelinge. Die Afrikaner, wat grootliks beskou word as deel van die tradisionele gereformeerdes, word te midde van die komplekse oorgangstydperk gekenmerk deur sterk individualisme, terughoudendheid en beterweterigheid (Du Toit et al. 2002:48; Oliver 2004:36-49; Jordaan 2008:8-9; Giliomee 2004:646; Hendriks 2000a:295). Hierdie manifestasies bevestig die gebrek aan eenvormigheid, asook die gebrek aan leierskap en leidinggewende instansies (Fraker \& Spears 1996:179; Schoeman 2008:2; Scholtz 2006:4). Die swygende meerderheid Afrikaners vrees die toekoms en die voortbestaan in Afrika; dit verduidelik die onvermoë tot Afrika-dienswilligheid. Ten diepste getuig die verwildering van roepingloosheid en onkunde rakende godsdiens. Die onverskilligheid, oppervlakkigheid en ylgelowigheid manifesteer konkreet in die krimping van tradisionele kerke.

Die enigste uitstaande wesenskenmerk wat histories as positief gerealiseer het, maar tydens die communitassituasie (Burger 1995:23-25) waarin die Afrikaner tans verkeer nog nie gemanifesteer het nie, is die dialektiek wat in die Afrikaner voorkom: '.. aan die een kant 'n fatalistiese afwagting van 'n gewisse kollektiewe nederlaag en finale ondergang, maar aan die ander kant is daar ook 'n misterieuse lewenskragtigheid' (Giliomee 2004:663).

\section{Afrika as multikulturele en postkoloniale tuiste}

Die Afrikaner vertoon na 450 jaar in Suid-Afrika 'n dubbele historisiteit (Van Coller 2007:55-59). Dit beteken dat die Afrikaner as Afrika-boorling, maar ook as afstammeling vanuit die ontwikkelde wêreld, binne 'n multikulturele, postkoloniale land leef. Die dualisme versterk die bestaande vervreemdingsindroom en die gebrek aan identiteit en selfvertroue wat daarmee gepaardgaan. Die vervreemdingstendens verdiep die toenemende onkunde rakende die SuidAfrikaanse multikulturele werklikheid. Die huidige SuidAfrikaanse werklikheid word op 'n afstand krities beskou, met die gevolg dat die werklikheid nie 'n deurslaggewende rol in dié isolerende groep speel nie. Die kerk word vermy, omdat skuldbesef deur die instansie aangeraak word (Giliomee 2004:633; Olivier 2005:37-38; Walls 1996:9-15). Sinisme teenoor die kerk neem toe, omdat die kerk skynbaar wil voorskryf, terwyl gereken word dat juis dié instansie die tradisionele gelowiges in die steek gelaat het.

'n Ander werklikheid bestaan derhalwe vir die tradisioneel Afrikaanssprekende, naamlik die globale werklikheid. As globale burger (Van Coller 2007:59) ontluik'n nuwe identiteit vir die losgeslane, identiteitsoekende Afrikaner. 'n Nuwe denksisteem, sonder godsdienstige reformasie, ontkiem as tuiste vir die nuwe identiteitsvorming. Die internet as nuwe identiteitgewende kultuurmekka neem aan die begin van die 21ste eeu die plek van godsdiens in en bied 'n veilige en bevredigende tuiste (Hendriks 1996:143).

Afrika as deel van die ontwikkelende wêreld vertoon duidelik 'n ander werklikheid as die van die Afrikaner van die ontwikkelde wêreld; ook godsdiens word deur die twee wêrelde verskillend benader en beleef (Van der Walt 1997; Walls 1996: 53-54). Die Afrikaner, binne hul benadering van die ontwikkelde wêreld, is onbewus van 'n hartsverandering wat onafwendbaar op alle gebiede moet plaasvind (Du Toit et al. 2002:48; Niemandt 2007:53). Vanweë die afsydige 
houding en onttrekking aan godsdienstige instellings, verdiep die onkunde (rakende die missionêre taak soos beveel in die Groot Opdrag) (Cameron et al. 2005:54, 62; Erasmus \& Hendriks 2003:87; Oliver 2007:23-40). Bekering terug na Christusgesentreerde denke aan die hand van die nuwe-wyn-nuwe-sak-beginsel (Mat 9:17) is 'n verdwynende verskynsel en getuig van sterwende kerke (vgl. Walls 1996:24, 25), tensy die 'lewenskragtigheid' op 'misterieuse' wyse spoedig begin manifesteer.

\section{Ekklesiologiese faktore}

Ekklesiologiese faktore as oorsaak van kerkkrimping binne die tradisioneel Afrikaanssprekende gereformeerdes is ter sprake wanneer 'n wanbalans in die eenheidsisteem van opbou en uitbou, soos beveel word in die Groot Opdrag, in so 'n mate voorkom dat kerkgroei beïnvloed word. Na aanleiding van ' $n$ steekproef wat gedoen is in die Gereformeerde Kerke in Suid-Afrika kan bevestigend gestel word dat 'n institusionalistiese denkraamwerk (I-denkparadigma) op dominante wyse binne die tradisionele ekklesiologie voorkom. Dié denkwyse is so omvattend dat dit reeds die intensiteit van 'n krisissituasie bereik het (De Wet 2000:3-7; Hendriks 1999:17-19; Walls 2002:274). Die situasie verdiep egter toenemend, aangesien gereformeerdes nie bewus is van die dringendheid van die krisis van denke nie (Bosch 1991:2; Schwarz 1999:7).

Die I-denkraamwerk het oor dekades 'n wanbalans in die ekklesiologie daargestel. Tans manifesteer die wanbalans deur blokkasies of hindernisse. In enige denkraamwerk is daar twee pole, 'n statiese en 'n dinamiese pool. 'n Wanbalans kom na vore indien een pool ten koste van die ander domineer. In die geval van die gereformeerdes, val die fokus op die statiese pool ten koste van die dinamiese pool. Die kerk as lewende organisme vertoon dan ongesond of ongebalanseerd. As gevolg van die langdurige ongesonde praktyk is die sterwensfase reeds bereik (Schwarz 1999:7-21).

Die sterk punt van die gereformeerde stroom, naamlik suiwer Skrifnavolging, vertoon binne die krimpende kerke die teendeel. Die sterk punt is deur 'n ongebalanseerde denkraamwerk onbetwisbaar gewysig om as die swak punt van die tradisioneel Afrikaanssprekende gereformeerdes na vore te kom (Burger 1999:116; Van der Walt 2006:31; Van Rooy 2006:22; Van Rooy 2007b:32). Die oortuiging dat suiwer volgens die Skrif geleef word en dat die tradisionele kerke dus 'beyond question' [ongetwyfelde sekerheid] (Schwarz 1999:7) is, is die leuen wat in onbewustheid van die waarheid geleef word en wat lei tot die enorme krisis waarin die kerkpraktyk tans bestaan.

Die krisispraktyk kom neer op 'n denkraamwerk waar die balans tussen opbou en uitbou volgens die Groot Opdrag nie gehoorsaam geleef word nie. Inteendeel, eie insigte word in skynbare nederigheid ononderhandelbaar verheerlik, naarstige soeke na sekerheid projekteer onuitgesproke wanhoop en vrees en realiseer in onbereidwilligheid tot aanpassende hervorming (Botha 2006:22; Van Niekerk 2007:14). Blokkasies of hindernisse kom na vore deur tekens van objektiwisme, heteronomisme, formalisme, rasionalisme en selfs die onbewuste teenwoordigheid van magiese konnotasies (bv. dat sekere Skrifgedeeltes genoem moet word en daardeur word gebedsverhoring outomaties verseker) (Schwarz 1999:24-32, 42, 191-194). Die 'veilige' en 'heilige' gereformeerde tradisies en 'n dogma van 'beyond question' [ongetwyfelde sekerheid] waarbinne die 'susterkerke' 'knus gekluister' (Hendriks 2003) leef, is die ontnugterende tradisioneel-kerklike leuen van die 21ste eeu (Joubert 2007:12). Die gereformeerde 'oorlewingstryd' (Hendriks 2003; 1996:142-144; 1999:17-19; Oliver 2007:23-40; Van Rooy 2006:22), wat weens ontoereikende kerklike praktyke binne gemeentes beleef word, versterk die verlamming wat in gemeentes heers (Botha 2006a:47; Burger 1999:150).

Die verlamde en verlammende denkwyse getuig van onkunde, of van vergeetagtigheid rakende die feit dat onstabiele tye die teelaarde is vir die voortgang van die evangelie, dat die eb en vloei van groeitendense algemene kennis behoort te wees en dat gelowiges voortdurend gerat moet wees om dienooreenskomstig denk-aanpassings te maak (Burger 2007:12; Hendriks 1996:143; Roxburgh 1997:2636). Omdat die denkwyse die tekens van veranderinge nie kan lees nie, word die huidige oorgangstydperk as baie ontwrigtend beleef. Sodanig-denkendes weet nie dat veranderende tye in die lig van die Bybel nuut verstaan móét word en dat aanpassing deur oop denke aan die hand van die Groot Opdrag beveel word nie. Menslike denke verander immers nie die waarheid van die Bybel nie, maar wel die nuut lees en nuwe toepassing daarvan, ten einde sinvolle optrede te verseker (Burger 1999:8; Olivier 2005:75).

\section{Kenmerke van kerkkrimping en kerkgroei}

Schwarz (1999:6-18) het ongeveer drie dekades gelede 'n omvattende ondersoek na redes van kerkgroei begin. Die Skrif is as uitgangspunt geneem en kenmerke van gesonde en dus groeiende gemeentes, is aan die hand van kwalitatiewe en kwantatiewe groei bestudeer. Kwalitatiewe en kwantitatiewe groei is sinoniem vir groei deur gemeentelike opbou en uitbou as eenheidsisteem. Opbou en uitbou is ingebed in die Groot Opdrag en gehoorsame uitvoering van Jesus se laaste bevel lei tot missionêre denke. Die teendeel van gehoorsame denke manifesteer gevolglik op elke terrein van die ekklesiologie as menslike aktiwiteit wat uit menslike denke voortspruit.

Schwarz het binne die ekklesiologie agt terreine geïdentifiseer. Binne elke terrein is missio Dei die bepalende faktor vir groei of krimping, na aanleiding van opbou en uitbou. Die terreine is: spiritualiteit, bediening, aanbidding of eredienste, kleingroepe, evangelisasie, strukture, leierskap en verhoudings (Schwarz 2000).

\section{Kenmerke waarbinne wanbalans manifesteer}

\section{Spiritualiteit (godsdienstigheid)}

Spiritualiteit gaan oor die verstaan van die teenwoordigheid of aktiwiteit van God in die mens (Smit 1995:24). Gereformeerdes beleef spiritualiteit en geloof op so 'n wyse dat ervaring of belewing nie soveel klem kry nie (Du Toit 
et al. 2002:8-12). Weens die ingrypende veranderinge in die huidige oorgangstydperk is ook dié godsdiensbelewing aan aanpassings onderworpe. Twee ontwikkelende strome manifesteer rakende spiritualiteit. Eerstens, die vermindering van godsdienstigheid en tweedens, die ontluiking van 'n anderse spiritualiteit. Die anderse spiritualiteit fokus sterk op die belewing deur ' $n$ lewende verhouding met Christus (Olivier 2006:141; Tickle 2008:123).

Die gevestigde I-denkwyse het tradisioneel sekerheid in die navolging van dogma (staties) gekry. Die afwesigheid van passie of belewing (organies) lei tot 'n wanbalans wat verder ook tot uiting kom deur ortodoksie, formalisme, absolutisme, fundamentalisme, rasionalisme en slaafse kerkorde-navolging.

\section{Bediening}

Bediening (kerugma, diakonia, koinonia, leitourgia) word deur die mens (denke) binne 'n gebroke bestel, so effektief moontlik daargestel (Burger 1999:113). Tradisioneel geskied die bediening deur ampswerk. Die bedieningsbegrip vertoon egter 'n wanbalans. $\mathrm{Na}$ aanleiding van Romeine 12:4-8, Efesiërs 4:11-16 en 1 Korinthiërs 12:27-31, is die hele gemeente interafhanklik en mede-aanspreeklik vir die opbou en uitbou van die bediening deur die aanwending van elkeen se gawes (Burger 1999:189, 194-196; Venter, 1996:80). Afwesigheid van gawe-georiënteerde bediening lei tot (Burger 1999:108-110; Niemandt 2007:40; Van der Walt 2006:31; Van Rooy 2007b:31-32):

- gemaksones

- middelmatigheid

- onderfunksionering

- ingekeerdheid

- gebrek aan moed of toewyding

- vrees vir dwaling

- verknogtheid aan kontrole

- die uitbrand van die pastor en gevolglike verlating van die beroep

- onkunde van wat gemeentebou en dienskneggestaltes behels.

\section{Aanbidding of eredienste}

Aanbidding dui nie net op eredienste nie, maar enige samekoms waar daar twee of meer gemeentelede byeen is (Burger 1999:196) en wat gegrond is op die Groot Opdrag, deurdat geestelik opgebou word, maar ook uitgereik word (Venter 2006:4). Wanbalans as gevolg van die I-denkparadigma manifesteer veral rondom die aanname rakende die teenwoordigheid van God, rondom die rol van die pastor en predikants-opleiding, asook rondom blokkasies tydens die erediens.

Teenwoordigheid van God: Aanbidding veronderstel die teenwoordigheid van die Gees (Olivier 2006:120). Tog is die werking van die Gees nie outomaties nie, aangesien die Woord alleenlik uitwerking het wanneer God deur sy Gees wil werk (Floor 1979:123; Schwarz 1999:9). 'n Kerk vol mense, maar sonder die Gees, is in wese nie meer kerk nie (Van Rooy 2007a:39).
Die rol van die pastor en predikants-opleiding: Omdat gebroke mense die taak het om deur Woordverkondiging God aan die woord te bring, is die gevaar dat God se doel ook op gebroke wyse verrig sal word. Die pastor wat nie moeite doen om sinvolle prediking te lewer nie, wat nie in 'n lewende verhouding met God leef nie en bloot met 'moet'-preke (Warren 2005:176) binne verstokte en waardelose liturgie (Du Toit et al. 2002:27) voortgaan om die 'frozen chosen' ['n individu of bepaalde groep wat hulself as uitverkore beskou maar ' $n$ doodsheid toon in die manier van doen.] (Moes 2007:4) tevrede te hou, lei tot gebrek aan voortdurende hervorming, asook tot teleurstelling onder gemeentelede wat 'Skrifkorrektheid as afgod' (Botes 2006:48) nie wil dien nie. Swaar voordragte en gelade taal bewerkstellig afstand en versterk wettisisme en intellektualisme (Wijnbeek 2007:40). Ware relevansie, geestelike entoesiasme en inspirerende aanbidding word in die huidige oorgangstyd gesoek, met die gevolg dat tradisionele kerkbesoek afneem (Breytenbach 2007:4-7).

Die eise wat aan 'n pastor gestel word, is hoog en talle predikante toon twyfel in die taak. Dit kom na vore wanneer die predikant as produk van 'powere teologie' bloot deur kennis gevorm is, terwyl ywer en Geesvervulling nie ontwikkel het nie. Die gevolg is dat die gemeentes waar sodanige predikante werk, benadeel word deurdat 'n 'geestelike baba' en 'n 'teologiese analfabeet' op 'n troontjie verantwoordelik is vir die gemeentelike groei (Van Rooy 2007a:39; Greenleaf 1996:269-275, 191-305). Die onvermoë om die ontwikkelende samelewingsbehoeftes te interpreteer en die Groot Opdrag binne die 500-jaarlikse golfbeweging, die societas of communitasfases, asook die lewenssiklus van gemeentes as missionêre hoofsaak te verstaan, toon dat I-denke grootliks deel uitmaak van die teologiese opleiding.

Blokkasies tydens eredienste: Blokkasies tydens eredienste manifesteer weens ' $n$ lewensvreemde liturgie wat nie balans hou met die ontwikkelende tydsgewrig nie. Oordrewe stigtelikheid, min inspirasie, spontaniëteit, emosie en vriendelikheid, uitgerekte besluitneming (bv. die vrou in die amp, kelkies, omdigtings), beperkte deelname deur gemeentelede, asook die gebrek om vrese en behoeftes aan te spreek, stimuleer die kritiese denke en pragmatiese houding van hedendaagse gemeentelede en lei tot afname in kerkbesoek (Du Toit et al. 2002:27, 244; Olivier 2006:23-25, 140; Schoeman 2006:47; Smit \& Vorster 2000:525; Van Helden 2002:1-30; Van Wyk 2006:6-7; Venter 2006:49).

\section{Kleingroepe}

Die voorkoms van kleingroepe, asook die nut en gewildheid daarvan, stem ooreen met die sterk sosiale skuif in die samelewing na kleiner, intiemer groepe waar holistiese bediening die eenheidsisteem van opbou en uitbou (Groot Opdrag) dien (Brouwer et al. 2007:154; Strong 2007:128). Afwesigheid van kleingroepbediening fokus op gebreke rakende leierskap, lidmaatbemagtiging, geborgenheid, gawes, evangelisasie en Bybelkennis (Du Toit et al. 2002:39; Hendriks 1993:548-550; 2003; Schwarz 1999:171-172).

\section{Evangelisasie of sending}

Hierdie kenmerk is die missie van die kerk en spruit direk voort uit die Groot Opdrag. Sonder evangelisasie of sending 
is groei onmoontlik. Dit impliseer evangelieverkondiging as 'n onvoorwaardelike liefdesdiens (Burger 1999:88-91; Olivier 2006:120). Afwesigheid hiervan, asook stereotipe denke rakende evangelisasie of sending, vertoon nie 'n Christusgesentreerde identiteit nie (Hendriks 1999:285). I-denke fokus op die instandhouding van die instituut, derhalwe kry selfgesentreerde opbou ter wille van oorlewing, alle aandag (Burger 1999:91-93).

Die behoeftegeoriënteerde kerk ter wille van die gemeenskap is ongekend (Walls 2002:274, 277; Kerkblad 2007:41). Kerkloses of kerklosses ervaar die tradisionele I-ekklesiologie onaantreklik en lewensvreemd en aansluiting by sodanige kerke geskied selde. Volgens Keller (Kommers 2006:668), is die hoofstroomkerke effektief om kerkontwikkeling in hul onmiddellike omgewing te verhinder. Kerkplanting word weerstaan, aangesien dit as kompetisie gereken word.

Kerkkrimping ontbloot die ware toedrag van die gereformeerde ekklesiologie. Die wanbalans het reeds krisisafmetings begin aanneem deur die totale platval van die suster-'kerklike koek' (Kerkblad 2007:41; Oliver 2007:2340; Van Rooy 2007a:39-41; Wijnbeek 2007:43-45). Groei kan nie plaasvind nie, omdat die Gees die terrein nie as goed voorbereide en missionêr-gesonde grond ag nie (Jackson 2007b:7; Walls 2007:274).

\section{Strukture}

Die instituut as struktuur staan altyd in die konteks van die apostolaat en nie andersom nie (Olivier 2006:75, 85, 133). Die daarstel van strukture na binne en na buite is mensewerk op grond van mensedenke; denke wat veronderstel is om voort te spruit uit gerigtheid op die Groot Opdrag (Schalekamp 2005b:23-28). Wanbalans kom na vore wanneer strukture as beginsels verhef word teenoor strukture wat funksioneel of effektief bydra tot opbou en uitbou van die gemeente. Strukture wat uitgedien is, moet gewysig word (Van der Walt 2006:31). Indien, byvoorbeeld, die kerkgebou as struktuur (bv. estetika, simboliek, tegnologie) nie waardetoevoegend is tot die spiritualiteit van die kerkganger nie, indien tradisies hoër geag word as die hedendaagse mens, of indien bedieningstrukture lomp of oneffektief funksioneer, word afstand by die hedendaagse mens bewerkstellig en affekteer dit gereelde kerkbesoek.

Die krag van die institusionele struktuur wat sekerheid as anker bied, benadeel buigbaarheid en vertraag aanpassing (Jackson 2007a:13). Weens ontvolking en verstedeliking besit plattelandse dorpies groot kerke vol leë banke. Historiese en emosionele redes vertraag dat afstand daarvan gedoen word en dat aanpassings bedink word.

\section{Leierskap}

Leierskap in die ekklesiologie is menslike dienswerk met die oog op ander mense, ter wille van die koninkryk (Burger 1999:182-189). Alle dienswerk begin uiteraard by menslike denke en juis hierdie feit is die grootste belemmering in leierskap (Olivier 2006:141). Efesiërs 4:12 stel duidelik dat gelowiges bemagtig of toegerus moet word vir hul diens.
Indien mede-eienaarskap deur betekenisvolle dade nie deur leierskap bewerkstellig word nie, verloor die ontmagtigde lidmaat sy gevoel van betrokkenheid en gevoel van behoort. Die pastor as leier se denke is grootliks nie gerig om societas, as grondslag vir missionêre aanpak as die missie van elke kerk voortdurend daar te stel en die proses van dissipelskap (opbou) tot versterkende identiteit te vestig nie.

Verder bestaan daar skynbaar spanning tussen God se plan en taakformulering deur die leierskap en die gemeente. Dit toon gebrek aan geoefende verbondsdenke en gehoorsaamheid (Burger 1999:95, 96; Warren 1989:34). Afwesigheid van vervul wees met die Gees realiseer in 'wankelmoedige leierskap' (Warren 2005:16) wat weer lei tot gebreke in die bediening soos selfgerigtheid, analitiese leierskap en stagnasie wat die werk van die Gees bemoeilik (Niemandt 2007:160-161). Gebrek aan toerusting (Van Rooy 2007b:31-32) en bemagtigde gawe-gerigte lidmate dra by tot oneffektiewe opbou asook uitbou. Waar wanopvattings onder predikante bestaan, byvoorbeeld dat hy insae in alles en oor almal moet hê, 'alles' in die gemeente moet doen en as superleiersfiguur op ' $n$ troontjie verkeer (Roxbourgh 1997:64), bewys navorsing dat kerkgroei (uitbou) weinig voorkom.

\section{Verhoudings}

Waar liefdevolle verhoudings as vrugbetoon afwesig is, is 'n tuiste-vriendelike kerk ook afwesig (Olivier 2006:84116). Indien wettiese of liberalistiese aspekte heers, word deurgaans probleme met vrugbetoon ervaar wat ten diepste skakel met gebrekkige identiteitsbesef (Burger 1999:52, 74, $893,141,142)$. Die hoeveelheid of gebrek aan energie wat ekklesiologies ingesit word, toon die mate van gemeentelike identiteit. Identiteit behels eenheid, heiligheid, algemeenheid en apostoliteit (Schalekamp 2005a:24-27) en word deur leitourgia, koinonia, kerugma en diakonia gekanaliseer met die oog op die missie, begrond op die Groot Opdrag (opbou en uitbou). Indien laasgenoemde nie die uitgangspunt is nie, manifesteer voorafgaande ook op ongebalanseerde wyse. Die gebrek aan identiteit en missie wat uitgeleef word, lei tot ongeloofwaardigheid. Liefdevolle verhoudings en dade wat nie praktyk is nie, affekteer die gemeentelike atmosfeer, so ook die afwesigheid van vriendelikheid, gasvryheid, betrokkenheid, om saam te verwyl of oor en weer te kuier. Met sekerheid kan aangeneem word dat meningsverskille, groepering, twis en onverdraagsaamheid teenoor medegemeentelede ook binne sodanige ongebalanseerde ekklesiologie voorkom.

Indien die teenwoordigheid van God nie die denkraamwerk rig nie, word in kerkisme en voorskriftelikheid verval (Botha 2006:22; Olivier 2006:23-25). Met die Groot Gebod as afwesige dryfkrag agter die Groot Opdrag, kan die liefdesbeginsel oor tale, rasse en gelowe in die praktyk binne 'n eenheidsisteem van opbou en uitbou nie gebalanseerd ontwikkel nie. Indien die mens nie deur opofferings, selfverloëning en geloof die noodsaaklike behoefte aan verhoudings binne God se raamwerk voorsien nie, kom die 'warm kop' en 
die 'koue hart', kenmerkend van die institusionalistiese denkraamwerk, deur krimpende kerke na vore (Wijnbeek 2006:34).

Elke kenmerk van die tradisionele ekklesiologie vertoon wanbalans wat ontstaan vanweë die ongebalanseerde I-denkparadigma. Die wanbalans tussen opbou en uitbou en wat spruit uit die afwesigheid van die missionêre gerigtheid (Groot Opdrag) wat Jesus Christus self as riglyn vasgelê het, behoort denkendes binne die krimpende kerke tot drastiese, dringende en diepgaande bekering en reformasie aan die hand van die nuwe-wyn-nuwe-sak-beginsel (Mat 9:17) terug tot ' $n$ Christusgesentreerde denkraamwerk aan te spoor.

\section{Slotsom}

Kerkkrimping word toegeskryf aan 'n menigte vervlegte en komplekse faktore. Dit is die resultaat van altydveranderende meetbare en onmeetbare faktore, te midde van die onstuitbare voortstuwende beweeglikheid van die Christelike godsdiens. Binne die verbondsverhouding, wat op die Groot Opdrag berus, kan met sekerheid diep en drastiese aanpassings gemaak word om tydens die huidige oorgangstyd die nuwe-wyn-nuwe-sak-beginsel te bedink, reformerend tot dade oor te gaan en 'n nuwe totaal anderse identiteit, geskik vir die eise van die 21ste eeu, te bekom. Die ontluikende omstandighede in Suid-Afrika kan dan vierkantig in die oë gekyk word en die hand aan die ploeg geslaan word ter wille van kerkgroei onder al die nasies in hierdie land as uithoek van die aarde.

\section{Literatuurverwysings}

Altemeyer, B., 2004, 'The decline of organized religion in Western civilization' [Die agteruitgang van georganiseerde godsdiens in die Westerse beskawing], International Journal for the Psychology of Religion 14(2), 77-89, viewed 10 June 2008, from http://www.puk.ac.za:2048/login?url=http://search.ebscohost. com/login.aspx?direct=true\&db=rfh\&AN=ATLA0001447120\&loginpage=Login. asp\&site=ehost-live]

Barret, D.T., Kurian, G.T. \& Johnson, T.M., 2001, World Christian Encyclopedia. A comparative survey of churches and religions in the modern world [Wêreld Christelike Ensiklopidie: ' $n$ Vergelykende opname van kerk en gelowe in die moderne wêreld], Volume 1, Oxford, Oxford.

Beukes, A.P.J., 2007, Almanak, Jaargang 101, SENTEK.

Björk, D., 2006, 'The future of Christianity in Western Europe: the end of a world' [Die toekoms van die Christendom in Wes-Europa: Die einde van ' $n$ wêreld], Missiology 34(3), Jl:309-324, viewed 10 June 2008, from http://www.puk. ac.za:2048/login? url=http://search.ebscohost.com/login. aspx?direct=true\&db=r fh\&AN=ATLA0001521288\&loginpage=Login.asp\&site=ehost-live]

Bosch, D.J., 1991, Transforming mission - Paradigm shifts in theology of mission [Sending transformasie: Paradigma skuiwe in sending teologie], Orbis Books, New York.

Botes, H., 2006, 'Briewe van ons lesers: Koninkryksbouers of koninkrykslopers?', Kerkblad, Julie, 48.

Botha, G.N.V., 2006, 'Altyd reformerend! Die GKSA se roeping ook in 2006', Die Kerkblad Okt., 22-23.

Botha, N., 2006a, 'Nou ken ons ons ellende beter', Die Kerkblad Mei, 47.

Breytenbach, H., 2007, 'Die verskynsel van geestelike entoesiasme', Kompas 16(5), 4-7.

Brouwer, R., De Groot, K., De Roest, H., Sengers, E. \& Stopples, S. (reds.), 2007, 'Levend liggaam: Dynamiek van christelijke geloofsgemeenschappen in Nederland' [Die
lewende liggaam: Dinamiek van die Christelike geloofsgemeenskap in Nederland], Kok, Kampen.

Buchner, E., 2007, 'Geld, besittings gawe van God', Beeld, 03 September, p.12.

Burger, C., 1995, 'Gemeentes in transito - vernuwingsgeleenthede in 'n oorgangstyd', Lux Verbi, Kaapstad.

Burger, C., 1999, Gemeente en bediening 4: Gemeentes in die Kragveld van die Geesoor die unieke identiteit, taak en bediening van die kerk van Christus, BUVTON, Stellenbosch.
Cameron, H., Richter, P., Davies, D. \& Ward, F., 2005, Studying local churches: A handbook ['n Handboek vir die studie van plaaslike kerke], SCM Press, London.

Cilliers, J., 1994, 'Pneumatologie en metodologie: 'n homiletiese perspektief', Nederduitse Gereformeerde Teologiese Tydskrif 35(2), 251-255.

Crockett, A., \& Voas, D., 2006, 'Generations of decline: religious change in 20thcentury Britain' [Agteruitgang van geslagte: Godsdienstige veranderinge in die 20ste eeuse Brittanje], Journal for the Scientific Study of Religion 45(4D), 567584, viewed 10 June 2008, http://www.puk.ac.za:2048/login?url=http://search. ebscohost.com/login.aspx?direct=true\&db=rfh\&AN=ATLA0001555987\&loginpag $\mathrm{e}=$ Login.asp\&site=ehost-live]

De Klerk, B.J., 2000, 'Liturgiese identiteitsvorming as antwoord op die invloed van die verbruikerskultuur', In die Skriflig 34(4), 451-468.

De Wet, F.W., 2000, 'Geloofswaarneming - 'n Teologies-estetiese benadering tot Praktiese Teologie', Proefskrif voorgelê vir die graad Theologiae Doctor in Praktiese Teologie aan die Potchefstroomse Universiteit vir Christelike Hoër Onderwys.

De Wet, F.W., 2005, 'Om in die Gees te begin en in eie krag te eindig - die noodsaak van ' $n$ Skrifgefundeerde prakties-teologiese Pneumatologie', In die Skriflig 39(3), 505-525.

Dreyer, A., 2009, 'Hoe begin mens oor?', Beeld, 13 Januarie., p. 13.

Dreyer, P.S., 1990, Almanak, 84ste jaargang, Gutenberg, Pretoria-Wes.

Du Toit, B., 2000, God? Geloof in 'n postmoderne tyd, CLF-Uitgewers, Bloemfontein.

Du Toit, F., Hofmeyer, H., Strauss, P., Van der Merwe, J., 2002, Moeisame pad na vernuwing: Die NG Kerk se pad van isolasie en die soeke na 'n nuwe relevansie, Barnabas, Bloemfontein.

Erasmus, J.C. \& Hendriks, H.J., 2003, 'Religious affiliation in South Africa early in the new millennium: Markinor's World Values Survey' [Godsdienstige affiliasie in Suid-Afrika vroeg in die nuwe millenium: Markinor se Wêreld Waardes Opname], Journal of Theology for Southern Africa 117, 80-96.

Floor, L., 1979, Hy wat met die Heilige Gees doop, N.G. Kerkboekhandel, Pretoria.

Fraker, A.T. \& Spears, L.C. (eds.), 1996, The private writings of Robert K. Greenleaf Seeker and servant reflections on religious leadership [Die private geskrifte van Robert K. Greenleaf. Die refleksies van ' $n$ werksoeker en dienskneg op godsdienstige leierskap], Jossey-Bass Publishers, San Francisco.

Gaum, F., 1990, Jaarboek van die Nederduistse Gereformeerde Kerke, Jaargang 141, Nasionale Boekdrukkery, Kaap.

Giliomee, H., 2004, Die Afrikaners: 'n Biografie, Tafelberg, Kaapstad.

Gill, R., 2003, The 'Empty' Church Revisited [Herbesoek aan die 'leë' kerk], Ashgate, Burlington.

Greenleaf, R.K., 1996, Seeker and servant reflections on religious leadership [Die refleksies van ' $n$ werksoeker en dienskneg op godsdienstige leierskap], JosseyBass Publishers, San Francisco.

Hendriks, H.J., 1993, 'Die 1991-bevolkingsensus-tendense en die Afrikaanse kerke', Nederduits Gereformeerde Teologiese Tydskrif 34(4), 542-551.

Hendriks, H.J., 1996, 'Kerkspieël en die NGK statistiek in die wyer perspektief van die Suid-Afrikaanse bevolkingsensusse 1911-1991', Nederduits Gereformeerde Teologiese Tydskrif 37(1), 138-145.

Hendriks, H.J., 1999, 'Verwagting vir die nuwe millennium: Gaan Gereformeerde Kerke groei, kwyn of verdwyn?', Woord en Daad 13, 17-19.

Hendriks, H.J., 2000, 'Die Suid-Afrikaanse Godsdienstige landkaart aan die begin van die nuwe millennium: tendense in die eerste post-apartheid bevolkingsensus', Praktiese Teologie in Suid-Afrika 15(2), 73-97.

Hendriks, H.J., 2000a, 'Tussen ideologiese ontnugtering en 'n nuwe visie. Waarom Afrikaners se wiele pap is', Tydskrif vir Geesteswetenskappe 40(4), 292-295.

Hendriks, H.J., 2003, Die toekoms van die kerk, die kerk van die toekoms, besitig 10 Mei 2010, van http://academic.sun.ac.za/theology/Profiles/Profile_documents/ Prof_Jurgens_Hendriks_Intreerede.pdf

Heitink, G., 1979, Pastoraat als hulpverlening: inleiding in de Pastorale Theologie en Psychologie, 2de druk, Uitgeversmaatschappij J.H. Kok, Kampen.

Heitink, G., Pieterse, H.J.C. \& Vos, C.J.A., 2000, "n Poging tot saamdink', Praktiese Teologie in S.A. 15(2), 53-71.

Hofmeyer, J.W. \& Pillay, G.J. (ed.), 1994, A History of Christianity in South Africa ['n Geskiedenis van Christenskap in Suid-Afrika, Volume 1, HAUM Tertiary, Pretoria.

Jackson, N., 2007a, 'Terug na die kerk se DNS', Beeld, 19 Januarie, p. 13.

Jackson, N., 2007b, 'Gemeente se toekoms is blink', Beeld, 18 September, p. 7.

Jansen, A., 2008, "n Ark wat nooit sal sink', By-Beeld, 13 Desember, p. 14.

Jenkins, P., 2007, The next Christendom - The coming of global Christianity [Die volgende Christendom - Die koms van globale Christenskap], University Press, Oxford.

Jordaan, G.J.C., 2008, 'Afrikaanse gelowiges geroep om saam te staan', Die Kerkblad Mei, 8,9

Joubert, S., 2007, 'Genade is kern van geloof in God', Beeld, 12, 27 Augustus.

Kane-Berman, J. (ed.), 2007, South Africa Survey 2006/2007 [Suid-Afrikaanse Opname 2006/2007], South Africa Institute of Race Relations (SAIRR), Braamfontein.

Kerkblad, 2007, 'Teologiese studente doen sendingprakties', April, 41.

Kommers, J., 2006, 'Opwekking binnen de traditioneel-reformatorische kerken: over oprecht verlangen en grote verlegenheid', In die Skriflig 40(4), 667-690.

Moes, H., 2007, 'Kultuur en geloofsbelewing: vir die "frozen chosen"', Kompas 16(5), $4-7$. 
Niemandt, N., 2007, Nuwe drome vir nuwe werklikhede, Lux Verbi.BM, Wellington.

Nürnberger, K., 2002, 'The Spirit of God: A soteriological metaphor in Biblical history and its significance for us today' [Die Gees van God: 'n Soteriologiese metafoor in Bybelse geskiedenis en die hedendaagse betekenis daarvan], Scriptura 79(1), $55-80$

Oliver, E., 2007, 'Thoughts on writing Afrikaner church history in the 21st century' [Gedagtes oor die skryf van die Afrikaner geskiedenis in die 21ste eeu], Studia Historiae Ecclesiasticae 33(1), 23-40.

Olivier, I.J., 2006, 'The strategic task of the church in creating spaces for spirituality' [Die strategiese taak van die kerk in die skepping van ruimte vir spiritualiteit], PhD thesis, Dept. Practical Theology Northwest-University (Potchefstroom Campus).

Rall, M., 2007, 'Ondersoek wys rekenaar, TV neem plek van Bybel', Beeld, 02 Oktober, p. 12.

Roxburgh, A.J., 1997, 'The missionary congregation, leadership and liminality' [Die missionêre gemeente, leierskap en liminaliteit], Trinity Press International, Harrisburg.

Saarinen, M.F., 1992, The life cycle of a congregation [Die lewenssiklus van ' $n$ gemeente], The Alban Institute, New York City.

Schalekamp, M.E., 2005a, 'Multikulturele kerkplanting: Ons moet hande vat met ander gelowiges en kerke', Die Kerkblad Aug., 24-27.

Schalekamp, M.E., 2005b, 'Missiones Ecclesiae: 'n missionêre visie en strategie in gemeentebou ten opsigte van multikulturele kerkplanting', PhD proefskrif, Noordwes-Universiteit Potchefstroom.

Schoeman, J., 2006, 'Gaan oor interpretasie van die Bybel', Die Kerkblad 47, 7.

Scholtz, L., 2006, 'De la Rey dui op iets groters, waarom altyd "Afrikaner" net koppel aan "rassisme"?', Beeld, 04 Desember, p.4.

Schwarz, C.A., 1999, 'Paradigm shift in the church - How natural church development can transform theological thinking' [Paradigmaskuiwe in die kerk - Hoe natuurlike can transform theological thinking' [Paradigmaskuiwe in die kerk - Hoe natuurlike
kerkontwikkeling teologiese denkrigtings kan transformeer], Emmelsbüll kerkontwikkeling teologiese denkrigting
ChurchSmart Resources, Carol Stream.

Schwarz, C.A., 2000, Natural Church Development: A guide to eight essential Qualities of Healthy churches [Natuurlike Kerk Ontwikkeling: ' $n$ Gids tot agt essensiële kwaliteit van gesonde kerke], S.A. Church Wise, Randhart.

Smit, A., (red.), 1995, Gemeente en bediening 4. Nuut gedink oor leierskap in gemeentes. Die begeleiding van 'n Christelike geloofsgemeenskap, Lux Verbi, Kaapstad.

Smit, C.J. \& Vorster, J.M., 2000, 'Die GKSA en sy gereformeerde identiteit: Kan dit behou word in 'n postmoderne gemeenskap?', In die Skriflig 34(4), 515-533.

Stilma, L., 1988, Op zoek naar de oorzaken van kerkverlating [Op soek na die oorsake van kerkverlating], Ten Have, Baarn.

Strong, P., 2007, 'Romans 12:2 as an important paradigm for transformation in a Christian: a practical theological study' [Romeine $12: 2$ as 'n belangrike paradigma vir transformasie in ' $n$ Christen: ' $n$ Praktiese, telogiese studie], Thesis submitted for the degree PhD, Pastoral Studies, North-West University (Potchefstroom Campus).

Symington, J., 2007, Jaarboek van die Nederduitse Gereformeerde Kerke, Jaargang 158, Tydskrifmaatskappy van die NG Kerk, Wellington.
Tickle, P., 2008, The great emergence [Die groot navore kome], Baker Books, Michigan. Van Aardt, P., 2006b, 'Hele geslag wit mense verlaat SA', Rapport, 24 September, p. 4. Van Coller, H.P., 2007, Perspektief en Profiel 3, p. 55-59, Van Schaik Uitgewers, Pretoria.

Van der Walt, B.J., 1997, 'Afrocentric of Eurocentric? Our task in a multicultural South Africa. Scientific contributions of the Potchefstroom University for Christian Higher Education F2(67)' [Afrosentries of Eurosentries. Ons taak in ' $n$ multikulturele SuidAfrika. Wetenskaplike Bydraes van die Potchefstroomse Universiteit vir Christelike Hoër Onderwys], Brochures of the Institute for Reformational Studies.

Van der Walt, B.J., 2006 'Die Postmodernisme, ' $n$ verleentheid en 'n geleentheid', Die Kerkblad, Sept., 30-32.

Van der Walt, S.J. (red.) 2000, Almanak van die Gereformeerde Kerke in Suid-Afrika, Jaargang 126, United Litho, Potchefstroom.

Van der Walt, T., 2007, Die Messias het gekom!' $n$ Gids in die Evangelies vir toegewyde Bybelstudente, 2de (hersiene) uitgawe, Potchefstroomse Teologiese Publikasies, Potchefstroom.

Van Helden, S., 2002, 'Die huidige aktiwiteit van die belydende GKSA-vrouelidmaat', In die Skriflig 36(4), 1-30.

Van Niekerk, A., 2007, “n Woord onderweg', Beeld, 27 Oktober, p. 14.

Van Rooy, J.A., 2006, 'Ons sendingerfenis ... en die vrugte na 100 jaar', Die Kerkblad Sept., 21, 22.

Van Rooy, K., 2007a, 'Kan die Gereformeerde Kerke hoegenaamd nog met die evangelie uitreik?', Die Kerkblad, Apr., 39-41.

Van Rooy, K., 2007b, 'Sendingwerk in die toekoms ... Hoe en waarheen?', Die Kerkblad Apr., $30-32$.

Van Ruler, A.A., 1969, Theologisch werk [Teologiese werk], Deel I, Callenbach, Nijkerk. Van Wyk, J.H., 2006, 'Ek soek 'n nuwe kerk', Die Kerkblad Mei, 6, 7.

Venter, C., 1996, Uitkringende liefdesbetoon. Kommunikatiewe handelinge in diens van die onderlinge liefdesgemeenskap in die kerk, RGN, Pretoria.

Venter, C.J.H., 2006, 'Prediking wat transformeer - praktiesteologiese gesigspunte', In die Skriflig 39(2), 217-237.

Vogel, W., 2008, Almanak van die Gereformeerde Kerke in Suid-Afrika, Jaargang 134, V \& R Drukkery (Edms.) Bpk, Pretoria.

Walls, A.F., 2002, The Cross-cultural process in Christian history - Studies in the Transmission and Appropriation of Faith [Die Kruis-kulturele proses in die Christelike geskiedenis - Studies in die Oordrage en Bewilligheid van Geloof], T \& T Clark, Edinburgh

Ward, K., 2004, 'Is New Zealand's future churchless?' [Is Nieu-Seeland se toekoms kerkloos?], Stimulus, 12(2) viewed 10 June 2008, from http://www.puk. ac.za:2048/login?url=http://search.ebscohost.com/login.aspx?direct=true\&db=r fh\&AN=ATLA0001591483\&loginpage=Login. asp\&site=ehost-live]

Warren, R., 2005, Doelgerigte kerk, Struik Christelike Boeke, Kaapstad.

Wijnbeek, M., 2007, 'Die kerke loop leeg ... en leër ... en leër', Die Kerkblad Julie, 43-45.

Woodhead, L., 2004, 'An introduction to Christianity' ['n Inleiding tot Christenskap], Cambridge University Press, Cambridge. 